\section{Jack Smithson}

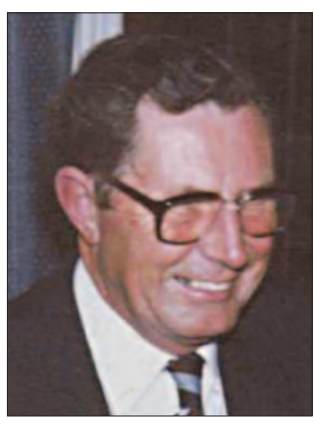

Samuel John (Jack) Smithson died on 6 September 2004 aged 77 after a long debilitating illness. Born on 4 March 1927 in Wheatley Hill, County Durham, he followed his elder brother Morris to Newcastle to study dentistry.

Jack qualified in 1949 and served his National Service as a dentist in the RAF throughout the north of England. Shortly after his commission ended, he joined the Northumberland County Council school dental service in Morpeth in November 1952. There he was promoted to Senior Dental Officer in the community dental service, and he later moved to Sunderland, mainly based in Washington, where he also spent a day a week working in the paediatric dentistry department of Newcastle Dental School.

He was popular with staff and patients alike, was a lifelong member of the British Dental Association and Chairman of the Public Dental Officers group of the Northern Division. He was very active in the BDA, serving on many committees, in particular helping to organise golf competitions. He was also a member

\section{Jack was a popular, kind, caring and compassionate clinician well suited to his profession.}

of the British Society for Paediatric Dentistry in the North East of England.

After his premature retirement in 1987 Jack continued to enjoy golfing, bowls, gardening, reading, music and his grandchildren, although the slow progression of his Parkinsons gradually reduced his mobility. In January 1992 he experienced the tragic loss of his childhood sweetheart, his wife Eunice. In 1997 he moved into a nursing home in Springwell near Washington.

Throughout his working life Jack was a popular, kind, caring and compassionate clinician well suited to his profession. Earlier this year his elder brother Morris died, but owing to his own illness Jack was unable to attend that funeral.

Those who had the pleasure of knowing Jack express our deepest sympathy to his daughters Susan and Ann, and his son Ian.

C.M. Jones

\section{John Maurice Richards}

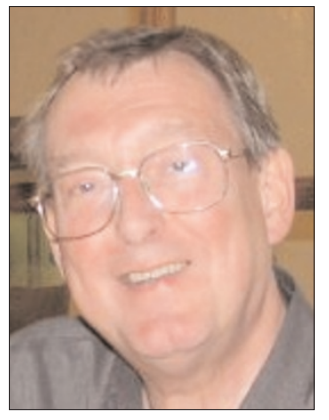

John Richards died on 19 October 2004, three months after his 65th birthday. Born in Romford, Essex, he attended Brentwood School and then The London Hospital Medical College Dental School from 1957 - where he spent the vast majority of his working life. In 1964 he became a part-time Lecturer in Conservative Dentistry, and then in 1969 added Principal of The London Hospital Community Dental Care Unit, thereby becoming full-time. His success in the first diet of the Diploma in Restorative Dentistry of the Royal College of Surgeons of Edinburgh in 1978, led to a full-time clinical academic post in conservative dentistry. For 12 years he played an active part in a large, busy department, teaching restorative dentistry to undergraduate and postgraduate students, dental therapists and dental surgery assistants. He also took responsibility for the day to day supervision of the Conservation Hospital Unit. In 1992, he changed direction and became a Senior Lecturer in Primary Oral Health Care and Accident Et Emergency within the Department of Oral \& Maxillofacial Surgery, overseeing an increased undergraduate involvement.

John established in-patient facilities at Honey Lane Hospital for adult handicapped patients and also took responsibility for out-patients of The Royal London Hospital group who presented with complicated medical histories. He set up the first clinic for 'at risk' patients at The London which was the forerunner of what would now be known as 'Special Needs Dentistry'. His knowledge of the management of the medically compromised patient was extensive and he also taught intravenous sedation. John never stopped learning, so that he could use that knowledge for the benefit of his patients and his students. He was responsible for the introduction of many infection control measures, including in 1987 the use of rubber gloves and protective spectacles.

\section{He set up the first clinic for 'at risk' patients at The London.}

John participated in many varied supporting activities for the School and College. He represented the University of London and United Hospitals in shooting, and was associated with The London Hospital Rifle Club for many years, being Senior President from 1976 to 1995 . He was also Senior President of The London Hospital Dental Society, 1984-85, Senior President of The London Hospital Clubs Union, 1987-88, President of the Blizard Club (the Senior Common Room for academic staff) 1998-2000, and Senior President to the Dental Society of Barts \& The London Medical and Dental Students Association, 2001-02. He was Secretary to the Non-Consultant Dental Staff Group and later was elected to the BDA Central Committee for University Dental Teachers \& Research Workers acting as the representative of staff at The London. He was a member of Council, Treasurer and later Vice President of the Odontological Section of the Royal Society of Medicine.

Around 2000 students will have passed through the Dental School at The London over the time that John was teaching. Undoubtedly, many will remember him from their time as undergraduate students, but his continuing activities as Secretary and later President of The London Hospital Dental Club (the Alumni Association), meant that he met many of them at the Annual Clinical Meeting.

John led a very full life and found time to be a Royal Automobile Club Steward for motor sport for nearly 20 years. He was a member of the Royal Photographic Society and various wildlife trusts. He liked nothing better than to spend his holidays travelling through France in his motor caravan with his friends, watching birds, enjoying a good meal and a nice glass of wine.

We extend our heartfelt sympathy to his family and to his close friends.

P. S. Wright 